\title{
SUBSTITUTED 1,3-PHENYL(PYRIDYL) PROPENONES AND DERIVATIVES WITH THIOSEMICARBAZIDIC GROUPS. STRUCTRURE - (HL-60) ANTILEUKEMIA ACTIVITY RELATIONSHIP
}

\author{
Ana Popusoi ${ }^{a^{*}}$, Nicanor Barba ${ }^{\mathrm{a}}$, Aurelian Gulea ${ }^{\mathrm{a}}$, Jenny Roy $^{\mathrm{b}}$, Donald Poirier ${ }^{\mathrm{b}}$ \\ ${ }^{a}$ Moldova State University, 60, Mateevici str., Chisinau, MD-2009, Republic of Moldova \\ ${ }^{b}$ Laboratory of Medicinal Chemistry, CHUQ (CHUL) - Research Center and Université Laval, 2705 Boulevard Laurier, \\ Québec City, G1V 4G2, Canada \\ *e-mail: popusoi.ana@gmail.com; phone: (+373 22) 577696
}

\begin{abstract}
Dimethylamino)phenyl-1-(4-isothiocyanatophenyl)prop-2-en-1-one was obtained from the corresponding $\mathrm{N}, \mathrm{N}$-dimethylthyoureas by elimination of dimethylamine at heating with gaseous hydrogen chloride in chloroform and 1-(4-isothiocyanatophenyl)-3-(pyridin-2-il)prop-2-en-1-one by treating 1,1-dimethyl-3-(4-(3(pyridin-2-il)-acryloyl)-phenyl)thyourea with acetic anhydride. The difference in the reactivity of the groups $>\mathrm{C}=\mathrm{O}$ and NCS in the synthesis with hydrazine hydrate and its derivatives allows the synthesis of some 1,3-disubstituted propenones with thiosemicarbazide groups (4- and 1,4-disubstituted) in good yields. From 4-substituted thiosemicarbazides and 2-formilpyridine thiosemicarbazones were obtained. In the case of some derivatives, the propenone group in the reaction with hydrazine hydrate allows the formation of pyrazole derivatives. All obtained compounds were investigated for antileukemia activity. It was found that this activity is more pronounced for thiosemicarbazide derivatives with two pyridine nuclei at concentrations $10^{-5}-10^{-7} \mathrm{~mol} / \mathrm{L}$.
\end{abstract}

Keywords: chalcones, isothiocyanatopropenones, thioureas, antileukemia activity.

\section{Introduction}

3-(4-(Dimethylamino)phenyl-1-(4-isothiocyanatophenyl)prop-2-en-1-one was obtained from the corresponding amine treated with triphosgene [1] in $80 \%$ yield. The authors [2] obtained this chalcone by the elimination of dimethylamine from 3-(4-(3-(4-(dimethylamino)phenyl)acryloyl)phenyl)-1,1-dimethylthiourea at heating with acetic anhydride, with an yield of $92 \%$. This compound shows high fluorescence and can be used as marker for proteins [3] and for the synthesis of luminescence polymer nanocomposites [4].

Thiosemicarbazides 4-and 1,4-disubstituited can be obtained at the addition of hydrazine and its derivatives to isothiocyanates $[5,6]$, or directly from $\mathrm{N}$-aril-N,N-dimethylthiourea [7]. The purpose of this study was to obtain biologically active compounds.

In the paper [8], the anticancer activity (for 5 types of cancer) was investigated for a class of chalcones with different substituents $\left(\mathrm{H}, \mathrm{CH}_{3}, \mathrm{OH}, \mathrm{OCH}_{3}, \mathrm{~N}\left(\mathrm{CH}_{3}\right)_{2}, \mathrm{Cl}\right)$ for both aromatic nuclei (A and B). In some cases the chalcones with $\mathrm{OCH}_{3}$ and $\mathrm{N}\left(\mathrm{CH}_{3}\right)_{2}$ groups show higher anticancer activity. The thiosemicarbazones of some chalcones show antitumor activity for HepG2 cell line [9]. The authors [10] investigated the anticancer activity for some thiosemicarbazones with the structures depicted in Figure 1.

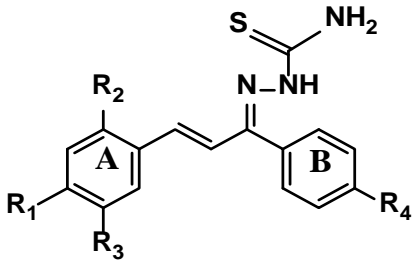

p) $\mathrm{R}_{1}=\mathrm{H}, \mathrm{R}_{2}=\mathrm{H}, \mathrm{R}_{3}=\mathrm{H}, \mathrm{R}_{4}=\mathrm{H}$

r) $\mathrm{R}_{1}=\mathrm{H}, \mathrm{R}_{2}=\mathrm{H}, \mathrm{R}_{3}=\mathrm{H}, \mathrm{R}_{4}=\mathrm{Me}$

s) $\mathrm{R}_{1}=\mathrm{H}, \mathrm{R}_{2}=\mathrm{H}, \mathrm{R}_{3}=\mathrm{H}, \mathrm{R}_{4}=\mathrm{OMe}$

v) $\mathrm{R}_{1}=\mathrm{H}, \mathrm{R}_{2}=\mathrm{F}, \mathrm{R}_{3}=\mathrm{H}, \mathrm{R}_{4}=\mathrm{Br}$ a) $\mathrm{R}_{1}=\mathrm{F}, \mathrm{R}_{2}=\mathrm{H}, \mathrm{R}_{3}=\mathrm{H}, \mathrm{R}_{4}=\mathrm{H}$

b) $\mathrm{R}_{1}=\mathrm{Cl}, \mathrm{R}_{2}=\mathrm{H}, \mathrm{R}_{3}=\mathrm{H}, \mathrm{R}_{4}=\mathrm{H}$

h) $\mathrm{R}_{1}=\mathrm{H}, \mathrm{R}_{2}=\mathrm{F}, \mathrm{R}_{3}=\mathrm{H}, \mathrm{R}_{4}=\mathrm{H}$

c) $\mathrm{R}_{1}=\mathrm{Br}, \mathrm{R}_{2}=\mathrm{H}, \mathrm{R}_{3}=\mathrm{H}, \mathrm{R}_{4}=\mathrm{H}$

i) $\mathrm{R}_{1}=\mathrm{H}, \mathrm{R}_{2}=\mathrm{Cl}, \mathrm{R}_{3}=\mathrm{H}, \mathrm{R}_{4}=\mathrm{H}$

d) $\mathrm{R}_{1}=\mathrm{OMe}, \mathrm{R}_{2}=\mathrm{H}, \mathrm{R}_{3}=\mathrm{H}, \mathrm{R}_{4}=\mathrm{H}$

j) $\mathrm{R}_{1}=\mathrm{H}, \mathrm{R}_{2}=\mathrm{Br}, \mathrm{R}_{3}=\mathrm{H}, \mathrm{R}_{4}=\mathrm{H}$

e) $\mathrm{R}_{1}=\mathrm{H}, \mathrm{R}_{2}=\mathrm{H}, \mathrm{R}_{3}=\mathrm{F}, \mathrm{R}_{4}=\mathrm{H}$

k) $\mathrm{R}_{1}=\mathrm{H}, \mathrm{R}_{2}=\mathrm{Me}, \mathrm{R}_{3}=\mathrm{H}, \mathrm{R}_{4}=\mathrm{H}$

f) $\mathrm{R}_{1}=\mathrm{H}, \mathrm{R}_{2}=\mathrm{H}, \mathrm{R}_{3}=\mathrm{OMe}, \mathrm{R}_{4}=\mathrm{H}$ m) $\mathrm{R}_{1}=\mathrm{H}, \mathrm{R}_{2}=\mathrm{NO}_{2} \mathrm{R}_{3}=\mathrm{H}, \mathrm{R}_{4}=\mathrm{H}$

g) $\mathrm{R}_{1}=\mathrm{H}, \mathrm{R}_{2}=\mathrm{H}, \mathrm{R}_{3}=\mathrm{NO}_{2}, \mathrm{R}_{4}=\mathrm{H}$

n) $\mathrm{R}_{1}=\mathrm{H}, \mathrm{R}_{2}=\mathrm{Ph}, \mathrm{R}_{3}=\mathrm{H}, \mathrm{R}_{4}=\mathrm{H}$

o) $\mathrm{R}_{1}=\mathrm{H}, \mathrm{R}_{2}=\mathrm{OCH}_{2} \mathrm{Ph}, \mathrm{R}_{3}=\mathrm{H}, \mathrm{R}_{4}=\mathrm{H}$

q) $\mathrm{R}_{1}=\mathrm{H}, \mathrm{R}_{2}=\mathrm{H}, \mathrm{R}_{3}=\mathrm{H}, \mathrm{R}_{4}=\mathrm{Br}$

t) $\mathrm{R}_{1}=\mathrm{H}, \mathrm{R}_{2}=\mathrm{H}, \mathrm{R}_{3}=\mathrm{H}, \mathrm{R}_{4}=\mathrm{Cl}$

w) $\mathrm{R}_{1}=\mathrm{Cl}, \mathrm{R}_{2}=\mathrm{H}, \mathrm{R}_{3}=\mathrm{H}, \mathrm{R}_{4}=\mathrm{oMe}$

u) $\mathrm{R}_{1}=\mathrm{H}, \mathrm{R}_{2}=\mathrm{H}, \mathrm{R}_{3}=\mathrm{Cl}, \mathrm{R}_{4}=\mathrm{Cl}$
Figure 1. The structure of chalcone thiosemicarbazide derivatives (a-w).

It was demonstrated that the anticancer activity depends on the nature and the position of the substituents in the structure. The 1,3-aril(heteryl-2-prop-1-ones chalcones at heating in a basic medium allow the formation of 1-thiocarbamoil-3-phenyl-5-heteroaril-2-pyrazoline with anticonvulsant and antidepressant properties [11].

The (1,3-aril(heteryl)propen-2-one) chalcones with thiosemicarbazidic groups (4-and 1,4-disubstituted) and respectively thiosemicarbazones are lacking in the literature and they became our object of study. 


\section{Results and discussion}

\section{Chemistry}

Introduction of groups 4- and 1,4-thiosemicarbazide in chalcones structure was performed by treating isothiocianato-1,3-prop-2-one 1a, b with hydrazine or with their derivatives 2a-d following the Scheme 1.

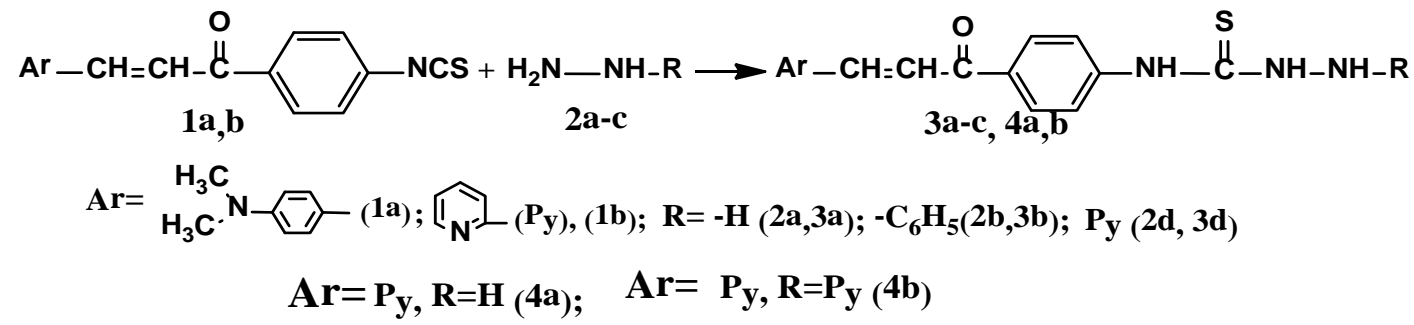

\section{Scheme 1. General synthesis of chalcone thiosemicarbazide derivatives (3a-c, 4a,b).}

Taking into account the high activity of NCS group in the reaction with nucleophile agents, the synthesis was realized at room temperature with a molar ratio of reagents of $1: 1$, to exclude the participation of the carbonyl group at condensation with hydrazine hydrate and its derivatives. Benzene was used as solvent, from which the hydrazinecarbothioamides 3a-c and 4a,b crystallized during the synthesis. Hydrazinecarbothioamides 3a and 4a which condense at heating were filtrated and washed first with benzene and after with water. They were used without further recrystallization. The other compounds can be recrystallized from corresponding solvents in a yield of 60-92\%.

The synthesis of N-(4-(3-(4-(dimethylamino)phenyl)acryloyl)phenyl)-2-(pyridin-2-ylmethylene)-hydrazinecarbothioamide 5a and N-(4-(3-(pyridin-2-yl)acryloyl)phenyl)-2-(pyridin-2-ylmethylene)- hydrazinecarbothioamide 6a (Scheme 2) is more efficient in the presence of acetic acid, when the solution of 2-formylpyridine is in excess. The solution of thiosemicarbazides 3a or $\mathbf{4 a}$ was added droplet by droplet. Thus, the interaction of chalconic $>\mathrm{C}=\mathrm{O}$ group with thiosemicarbazidic group was excluded. The yields of thiosemicarbazones $5 \mathbf{a}$ and $\mathbf{6 a}$ reached a value of $83 \%$ and $77 \%$ (Scheme 2).

4,5-Dihydro-1H-pyrazol-3-yl)phenyl)hydrazinecarbothioamides 7a and 8a were obtained through the sequence of reactions that is indicated in Scheme 3.

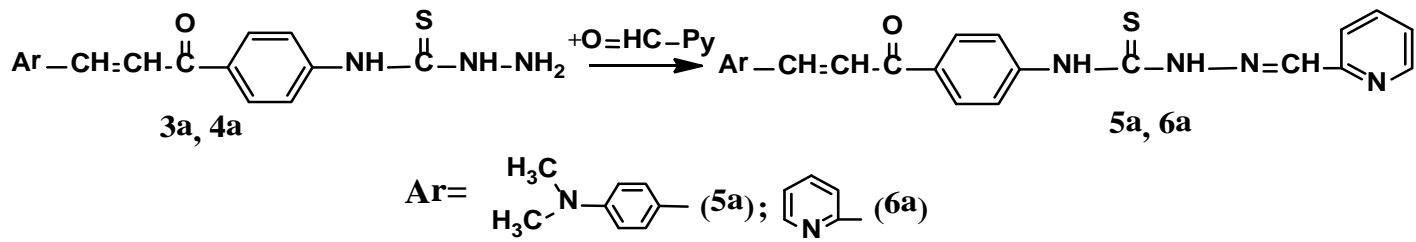

Scheme 2. Synthesis of hydrazinecarbothioamide (5a, 6a).

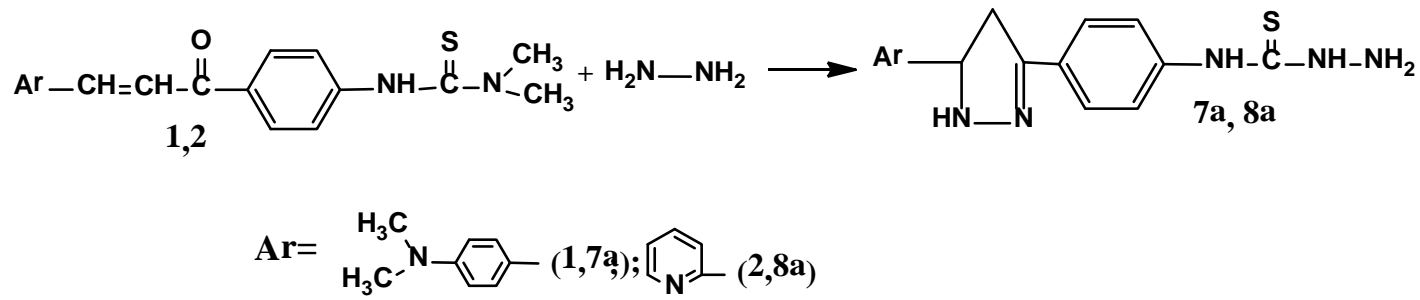

Scheme 3. Synthesis of chalcone derivatives $(1,7 a, 2,8 a)$.

First the N,N-dimethylthioureas 1,2 with hydrazine at room temperature transforms in hydrazones in pyridine, which without being isolated at heating it will cyclise in pyrazole derivatives [7]. In parallel, dimethylamine is substituted by hydrazine [11] with the formation of compounds 7a and 8a in good yields. Compound 7a was also obtained by an alternative method, from isothiocyanatophenylprop-2-en-1-one 1a, pyridine and hydrazine at room temperature, after that the mixture was heated. It could be possible that the same intermediate is formed, which is transformed into the final product 7a.

Compounds 9a and 10a (Figure 2) were obtained from 7a and $\mathbf{8 a}$ at heating in ethanol with 2-formylpyridine. 


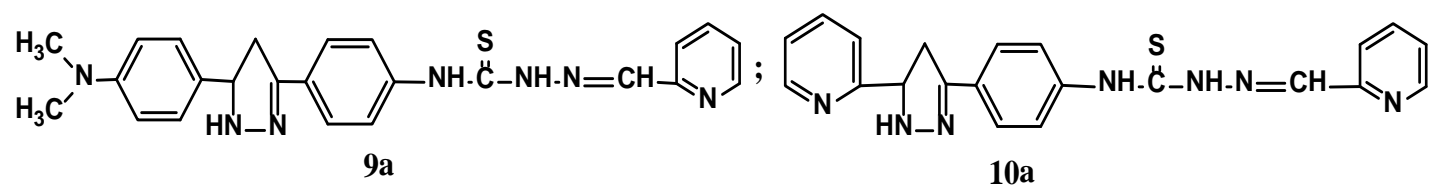

Figure 2. Structure of chalcone derivatives (9a, 10a).

\section{Biological Activity \\ Antiproliferative Activity of Human Leukemia HL-60 Cells}

For all obtained compounds the antileukemia activity was investigated. It is more pronounced for thiosemicarbazide derivatives with two pyridine nuclei at concentrations $10^{-5}-10^{-7} \mathrm{~mol} / \mathrm{L}$ (see Table 1).

The aryl isothiocyanates with different substituents in their structure are inactive against leukemia [12]. Isothiocyanatochalcone 1a and 1-(4-isothiocyanatophenyl)-3-(pyridine-2-yl)prop-2-en-1-one $\mathbf{1 b}$ are also inactive. Similarly, the N-phenylhydrazinecarbothioamide 11a is inactive. It was found that the modification of the -NCS fragment in compounds 1a and $\mathbf{1 b}$ by the addition of the hydrazine and its derivatives, leads to anticancer activity for all the chalcones 3a-d. Chalcone 3c, which contain residues of pyridine in the first position of the tiosemicarbazidic fragment, shows an inhibition of the antileukemia of $92 \%$ at concentration of $10^{-5} \mathrm{~mol} / \mathrm{L}$. It can be concluded that the introduction of the fragment $\left(\mathrm{CH}_{3}\right)_{2} \mathrm{~N}-\mathrm{C}_{6} \mathrm{H}_{4}-\mathrm{CH}=\mathrm{CH}-\mathrm{CO}-$ or $\mathrm{Py}-\mathrm{CH}=\mathrm{CH}-\mathrm{CO}$ - in the molecule of N-phenylhydrazinecarbothioamide 11a plays an important role to increase the anticancer activity. This activity increases when the fragment $\left(\mathrm{CH}_{3}\right)_{2} \mathrm{~N}_{-} \mathrm{C}_{6} \mathrm{H}_{4}-$ of the chalcone $3 \mathbf{c}$ is replaced by rest of pyridine, propenone $4 \mathbf{b}\left(100 \%, \mathrm{C}=10^{-5} \mathrm{~mol} / \mathrm{L}\right)$.

To highlight the role of the propenonic group on the anticancer activity on the propenones $3 \mathbf{a}, 4 \mathbf{a}, 5 \mathbf{a}$ and $\mathbf{6 a}$ the fragment $-\mathrm{CH}=\mathrm{CH}-\mathrm{CO}$ - was transformed in pyrazole heterocycle. For all obtained and studied samples 7a, 8a, 9a and 10a a sudden decrease of anticancer activity was observed (see Table 1). It was identified that for compound 10a with two pyridine nuclei the inhibitor activity decrease slower when is diluted and achieves $\sim 60 \%$ at concentration of $10^{-7}$ $\mathrm{mol} / \mathrm{L}$. The high anticancer activity for compound 10a can be explained by the formation of the strong hydrogen bonds between the inhibitor and the nucleic acid of the cancer cells [13].

Antiproliferative activity of compounds on human leukemia (HL-60) cells at three concentrations.

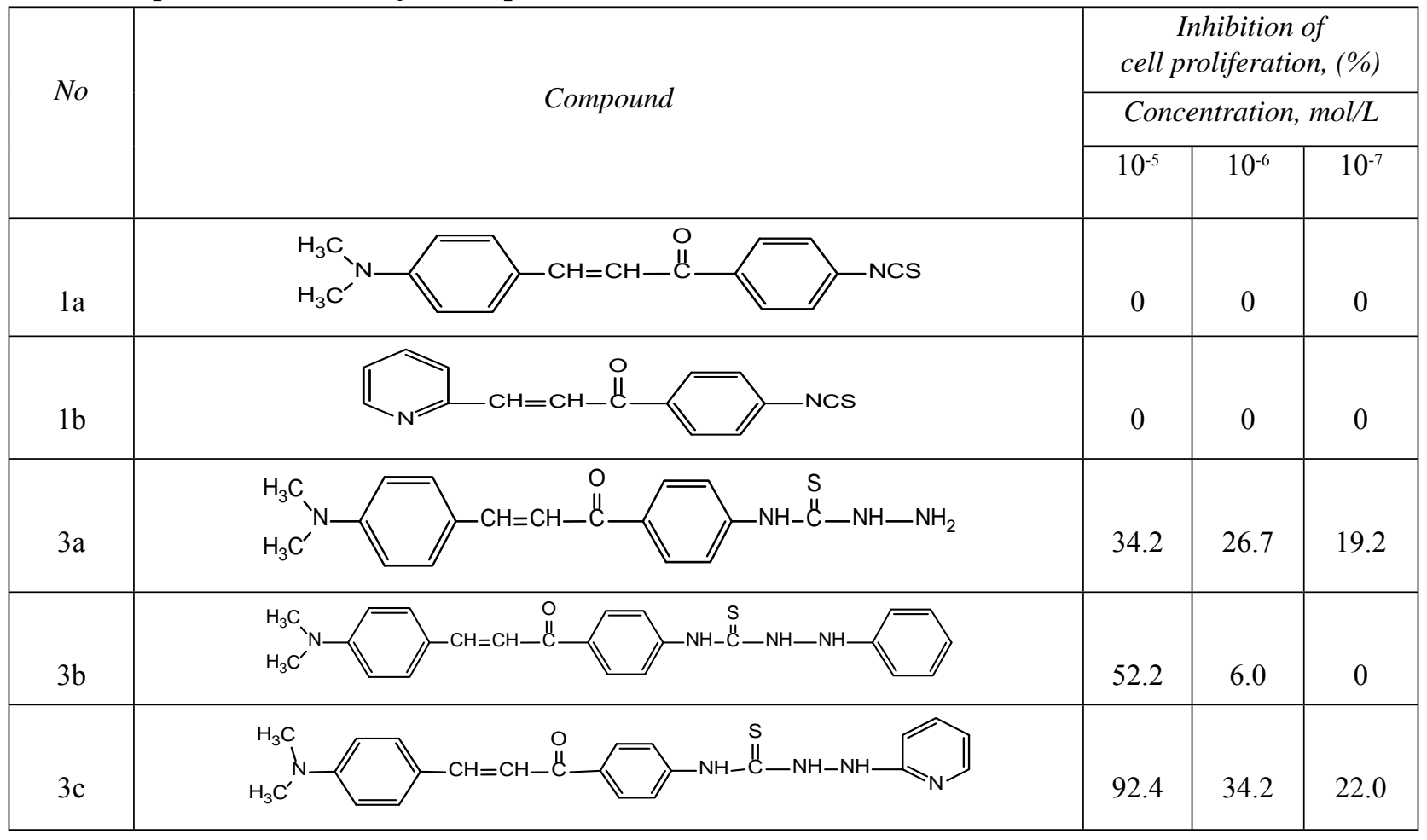


Continuation of the Table 1

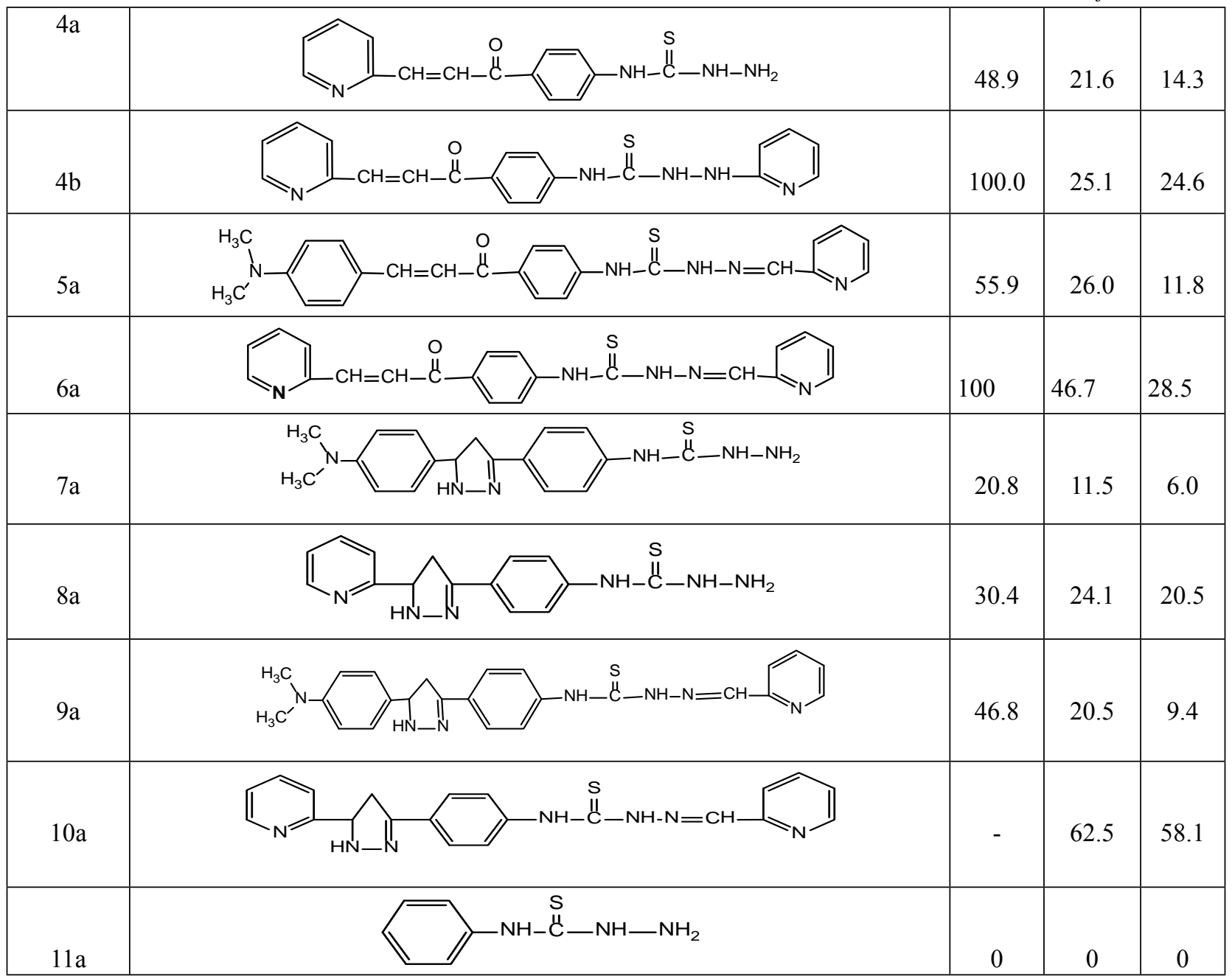

\section{Conclusions}

Ten new propenones and thiosemicarbazidic groups have been synthesized and characterized. The IR, ${ }^{1} \mathrm{H}-\mathrm{NMR}$ and ${ }^{13} \mathrm{C}$-NMR data were successfully used to elucidate the formation of the structure of compounds. All obtained compounds were investigated for antileukemia activity. It was found that this activity is more pronounced for thiosemicarbazide derivatives with two pyridine nuclei at concentrations $10^{-5}-10^{-7} \mathrm{~mol} / \mathrm{L}$.

\section{Experimental}

The structure of compounds 1a, b, 3a-c, 4a, b, 5a, 6a, 7a, 8a, 9a and 10a was confirmed by elemental and spectral analysis $\left({ }^{1} \mathrm{H}\right.$ and ${ }^{13} \mathrm{C}$ NMR). The ${ }^{1} \mathrm{H}$ and ${ }^{13} \mathrm{C}$ NMR spectra were recorded on a Bruker Avance III-400 spectrometer at room temperature. All chemical shifts $\left({ }^{1} \mathrm{H},{ }^{13} \mathrm{C}\right)$ are given in ppm versus $\mathrm{SiMe}_{4}$ using DMSO-d ${ }_{6}$ as solvent. Elemental analyses (C, H and N) were performed on an Elemental Analyzer Vario EL (III). Compounds 3a and 4a form insoluble in organic solvents polycondensed compounds at heating until the melting point. The melting points were determined with a Melting point meter A. KRUSS OPTRONIC Germany KSP-1N 90-26V/A1.

3-(4-(Dimethylamino)phenyl-1-(4-isothiocyanatophenyl)prop-2-en-1-one $\quad \begin{array}{lllllll}1 a & 0.7 & \mathrm{~g} & (0.002 & \mathrm{mol}) & \text { of }\end{array}$ 3-(4-(3-(4-(Dimethylamino)phenyl)acryloyl)phenyl)-1,1-dimethylthiourea 1 and $6 \mathrm{~mL}$ of chloroform were placed in one flask. After this, the solution was cooled and gaseous hydrogen chloride was passed through it. Once the mass of the mixture increase with $0.15 \mathrm{~g}$, the ampoule was welded and heated at $70^{\circ} \mathrm{C}$ for 3 hours. The resulting product was neutralized to $\mathrm{pH}=7$, the organic solution was dried with $\mathrm{Na}_{2} \mathrm{SO}_{4}$ and a part of the solvent was distilled. The final product was purified by chromatography on Silicagel (eluent hexane/benzene, 1/5). It was obtained $0.54 \mathrm{~g}(88 \%)$ of propenone 1a m.p. $136-138^{\circ} \mathrm{C}$ which corresponds with the literature results [2].

Elemental analysis and NMR data: Calculated of $\mathrm{C}_{18} \mathrm{H}_{16} \mathrm{~N}_{2} \mathrm{OS}$ (1a), \%: C-70.26, H-5.28, N-9.26. Found, \%: C-70.10, H-5.23, N-9.08. ${ }^{1} \mathbf{H}-\mathrm{NMR}$ (DMSO-d $\mathrm{D}_{6}$ ), ppm: $3.02\left(\mathrm{~s}, 6 \mathrm{H}, \mathrm{N}\left(\mathrm{CH}_{3}\right)_{2}\right), 6.74-8.20\left(\mathrm{~m}, 10 \mathrm{H},=\mathrm{CH}\right.$ and $\left.\mathrm{C}_{6} \mathrm{H}_{4}\right) .{ }^{13} \mathbf{C}-\mathbf{N M R}$ (DMSO-d $)_{6}$, ppm: $187.82(\mathrm{C}=\mathrm{O}), 181.39(\mathrm{C}=\mathrm{S}), 152.42(\mathrm{C}-\mathrm{N}), 145.14\left(-\mathrm{C}_{6} \mathrm{H}_{4}-\mathbf{C H}=\right), 137.11\left(-\mathrm{C}_{6} \mathrm{H}_{4}-\mathrm{N}=\mathbf{C}=\mathbf{S}\right), 145.14$, $134.39,131.45,131.15,129.46,126.67,122.59,122.01,111.54,40.65,40.44$. 
N-(4-(3-(4-(Dimethylamino)phenyl)acryloyl)phenyl)hydrazinecarbothioamide 3a. The mixture formed by 0.61 g (0.002 mol) 3-(4-(Dimethylamino)phenyl-1-(4-isothiocyanatophenyl)prop-2-en-1-one 1a, $0.13 \mathrm{~g}$ (0.0025 mol) hydrazine hydrate and $5 \mathrm{~mL}$ of ethanol was kept at room temperature for $30 \mathrm{~min}$. After, it was heated at $40^{\circ} \mathrm{C}$ for $5 \mathrm{~min}$. The CCM (silufol) show the total consumption of isothiocyanatochalcone 1a. The reacting mixture was cooled and the resulting crystals were filtrated and washed with ethanol. Yield $0.63 \mathrm{~g}$ (92 \%) of hydrazinecarbothioamide 3a, m.p. $>155^{\circ} \mathrm{C}$ (is polycondensatione).

Elemental analysis and NMR data: Calculated of $\mathrm{C}_{18} \mathrm{H}_{20} \mathrm{~N}_{4} \mathrm{OS}$ (3a), \%: C-63.50, H-5.92, N-16.47. Found, \%: C-63.53, H-6.01, N-16.84. ${ }^{1} \mathrm{H}-\mathrm{NMR}$ (DMSO-d $)$, ppm: 4.89 (m, 2H, NH $\left.{ }_{2}\right), 6.71-8.82$ (m, 10H, =CH, Ar-H), 10.10 (s, -NH-CS), $9.45\left(\mathrm{~s},-\mathbf{N H}-\mathrm{NH}_{2}\right) 3.46\left(\mathrm{~s}, 6 \mathrm{H},-\mathrm{N}\left(\mathrm{CH}_{3}\right)_{2}\right) .{ }^{13} \mathrm{C}-\mathrm{NMR}\left(\mathrm{DMSO}-\mathrm{d}_{6}\right), \mathrm{ppm}: 179.39(\mathrm{C}=\mathrm{S}), 187.75(\mathrm{C}=\mathrm{O}), 152.35\left(\left(\mathrm{CH}_{3}\right)_{2} \mathrm{~N}-\right.$ Ar- $\mathrm{CH}=\mathrm{CH}), 145.02(\mathrm{Ar}-\mathbf{C H}=\mathrm{CH}), 122.59(\mathrm{Ar}-\mathbf{C H}=\mathrm{CH}), 40.74\left(\mathrm{CH}_{3}\right), 131.13,129.09,128.93,124.42,123.83,116.53$, 112.22.

N-(4-(3-(4-(Dimethylamino)phenyl)acryloyl)phenyl)-2-phenylhydrazinecarbothioamide $3 \mathbf{b}$. To a solution of 0.61 g (0.002 mol) 3-(4-(Dimethylamino)phenyl-1-(4-isothiocyanatophenyl)prop-2-en-1-one 1a and $4 \mathrm{~mL}$ of benzene was added by droplet a solution of $0.21 \mathrm{~g}(0.002 \mathrm{~mol})$ phenylhydrazine in $2 \mathrm{~mL}$ of benzene. The reacting mixture was let at room temperature for 1 hour and after heated at $40-45^{\circ} \mathrm{C}$ for $20 \mathrm{~min}$. The end of the reaction was followed by chromatography by the consumption of isothiocyanatochalcone 1a. The resulting crystals were filtrated and recrystallized from ethanol. Yield $0.73 \mathrm{~g}(88 \%)$ of thioamide $3 \mathbf{b}$, m.p. $219-221^{\circ} \mathrm{C}$.

Elemental analysis and NMR data: Calculated of $\mathrm{C}_{24} \mathrm{H}_{24} \mathrm{~N}_{4} \mathrm{OS}$ (3b), \%: C-69.20, H-5.81, N-13.45. Found, \%: C-69.32, H-5.61, N-13.65. ${ }^{1}$ H-NMR (DMSO-d $)$, ppm: 6.73-8.10 (m, 15H, =CH, Ar-H), 10.12 (s, NH-CS), 9.96 (s, -NH-NH-Py), 8.16 (s, -NH-NH-Ar), $\left.3.42\left(\mathrm{~s}, 6 \mathrm{H},-\mathrm{N}\left(\mathrm{CH}_{3}\right)\right)_{2}\right) .{ }^{13} \mathrm{C}-\mathrm{NMR}$ (DMSO-d $)$, ppm: $187.93(\mathrm{C}=\mathrm{O}), 181.32(\mathrm{C}=\mathrm{S}), 148.34(-\mathrm{NH}-$ NH-Ar $), 143.71\left(-\mathrm{C}_{6} \mathrm{H}_{4}-\mathrm{NH}\right), 152.41\left(\left(\mathrm{CH}_{3}\right)_{2} \mathrm{~N}-\mathrm{Ar}-\mathrm{CH}=\mathrm{CH}\right), 145.18(\mathrm{Ar}-\mathbf{C H}=\mathrm{CH}), 122.58(\mathrm{Ar}-\mathrm{CH}=\mathrm{CH}), 40.92(\mathrm{CH})$, $134.65,131.16,129.39,124.20,116.56$.

112.24 .

2-Benzoyl-N-(4-(3-(4-(dimethylamino)phenyl)acryloyl)phenyl)hydrazinecarbothioamide 3c. The mixture of $0.61 \mathrm{~g}$ (0.002 mol) 3-(4-(Dimethylamino)phenyl-1-(4-isothiocyanatophenyl)prop-2-en-1-one 1a, $0.23 \mathrm{~g}(0.0021 \mathrm{~mol})$ 2-hydrazinylpyridine and $6 \mathrm{~mL}$ of benzene was kept at room temperature for 1 hour and after heated at $40^{\circ} \mathrm{C}$ for $5 \mathrm{~min}$. The total consumption of isothiocyanatochalcone 1a was checked by chromatography. The resulting mixture was cooled and the resulting crystals were filtered out. Yield $0.76 \mathrm{~g}(92 \%)$ of hydrazinecarbothioamide $3 d$ with $\mathrm{m} . \mathrm{p} .178-180^{\circ} \mathrm{C}$, (from ethanol).

Elemental analysis and NMR data: Calculated of $\mathrm{C}_{23} \mathrm{H}_{23} \mathrm{~N}_{5} \mathrm{OS}$ (3d), \%: C-66.16, H-5.55, N-16.77. Found, \%: C-66.18, H-5.52, N-16.79. ${ }^{1}$ H-NMR (DMSO-d $)$, ppm: 6.68-8.16 (m, 13H, =CH, Ar-H, Py-H), 10.10 (s, NH-CS), 9.97 (s, NHNH-Py), 8.65 (s, NH-NH-Py), $3.42\left(\mathrm{~s}, 6 \mathrm{H},-\mathrm{N}\left(\mathrm{CH}_{3}\right)_{2}\right) .{ }^{13} \mathrm{C}-\mathrm{NMR}\left(\mathrm{DMSO}-\mathrm{d}_{6}\right), \mathrm{ppm}: 187.92(\mathrm{C}=\mathrm{O}), 181.36(\mathrm{C}=\mathrm{S})$, 159.47 (-NH-NH- Py), $139.26\left(-\mathrm{C}_{6} \mathrm{H}_{4}-\mathrm{NH}\right), 152.42\left(\left(\mathrm{CH}_{3}\right)_{2} \mathrm{~N}-\mathrm{Ar}-\mathrm{CH}=\mathrm{CH}\right), 145.14(\mathrm{Ar}-\mathrm{CH}=\mathrm{CH}), 122.59(\mathrm{Ar}-\mathrm{CH}=\mathrm{CH})$, $131.16,124.33,116.58,112.24,107.94,40.65\left(\mathrm{CH}_{3}\right)$.

N-(4-(3-(pyridin-2-yl)acryloyl)phenyl)hydrazinecarbothioamide 4a. The mixture of $0.53 \mathrm{~g}(0.002 \mathrm{~mol})$ 1-(4-isothiocyanatophenyl)-3-(pyridine-2-yl)prop-2-en-1-one 1b, $0.13 \mathrm{~g}(0.0025 \mathrm{~mol})$ of hydrazine hydrate and $2 \mathrm{~mL}$ of benzene was stirred at room temperature for 2 hours until the total consumption of isothiocyanate 1b. After the mixture was cooled down and the formed crystals were filtrated, washed with water and dried. Yield $0.38 \mathrm{~g}(64 \%)$ of carbothioamide 4a, m.p. $169-171^{\circ} \mathrm{C}$.

Elemental analysis and NMR data: Calculated of $\mathrm{C}_{15} \mathrm{H}_{14} \mathrm{~N}_{4} \mathrm{OS}(4 a), \%$ C-60.38, H-4.73, N-18.78. Found, \%: C-60.47, H-4.84, N-18.97. ${ }^{1} \mathbf{H}-\mathrm{NMR}$ (DMSO-d $)$, ppm: 3.89 (m, 2H, NH $\left.{ }_{2}\right), 7.36-8.70(\mathrm{~m}, 10 \mathrm{H},=\mathrm{CH}, \mathrm{Ar}-\mathrm{H}), 10.50$ (s, -NHCS), $9.48\left(\mathrm{~s},-\mathbf{N H}-\mathrm{NH}_{2}\right) .{ }^{13} \mathbf{C}-\mathrm{NMR}\left(\mathrm{DMSO}-\mathrm{d}_{6}\right)$, ppm: $180.39(\mathrm{C}=\mathrm{S}), 188.09(\mathrm{C}=\mathrm{O}), 152.39(\mathbf{P y}-\mathrm{CH}=\mathrm{CH}), 144.96(\mathrm{Ar}-$ $\mathbf{C H}=\mathrm{CH}), 122.59(\mathrm{Ar}-\mathbf{C H}=\mathrm{CH}), 137.42,133.72,126.58,122.31$.

2-(Pyridin-2-yl)-N-(4-(3-(pyridin-2-yl)acryloyl)phenyl)hydrazinecarbothioamide 4b. The solution of $0.53 \mathrm{~g}(0.002$ mol) 1-(4-isothiocyanatophenyl)-3-(pyridine-2-yl)prop-2-en-1-one 1b, $0.22 \mathrm{~g}$ (0.002 mol) 2-hydrazinylpyridine and $4 \mathrm{~mL}$ of benzene was stirred at room temperature for 2 hours. After, the solution was cooled down and the resulting crystalline product was filtered and recrystallized from ethanol. Yield $0.64 \mathrm{~g}(85 \%) \mathrm{m} . \mathrm{p} .198-200^{\circ} \mathrm{C}$.

Elemental analysis and NMR data: Calculated of $\mathrm{C}_{20} \mathrm{H}_{17} \mathrm{~N}_{5} \mathrm{OS}$ 4b, \%: C-63.98, H-4.56, N-18.65. Found, \%: C-63.96, H-4.58, N-18.64. ${ }^{1}$ H -NMR (DMSO-d $)$, ppm: 6.78-8.36 (m, 13H, =CH, Ar-H, Py-H), 10.12 (s, NH-CS), 9.91 (s, NHNH-Py), 8.68 (s, NH-NH-Py). ${ }^{13}$ C-NMR (DMSO-d $)$, ppm: 187.92 (C=O), 181.36 (C=S), 159.47 (-NH-NH- Py), 139.26 $\left(-\mathrm{C}_{6} \mathrm{H}_{4}-\mathbf{N H}\right), 154.42(\mathbf{P y}-\mathrm{CH}=\mathrm{CH}), 145.17(\mathrm{Ar}-\mathbf{C H}=\mathrm{CH}), 122.56(\mathrm{Ar}-\mathbf{C H}=\mathrm{CH}), 131.16,124.33,116.58,112.24,107.94$.

N-(4-(3-(4-(Dimethylamino)phenyl)acryloyl)phenyl)-2-(pyridin-2-ylmethylene)hydrazinecarbothio-amide 5a. To the solution of $0.24 \mathrm{~g}(0.0023 \mathrm{~mol}) 2$-formylpyridine, $0.1 \mathrm{~g}$ of $\mathrm{CH}_{3} \mathrm{COOH}$ and $1 \mathrm{~mL}$ of dimethylformamide was 
added under stirring droplet by droplet to a of $0.68 \mathrm{~g}$ (0.002 mol) N-(4-(3-(4-(Dimethylamino)phenyl)acryloyl)phenyl) hydrazinecarbothioamide 3a in $2 \mathrm{~mL}$ of dimethylformamide during $30 \mathrm{~min}$ at room temperature and after heated at $40^{\circ} \mathrm{C}$. After, the reacting mixture was heated at $70^{\circ} \mathrm{C}$ for 3 hours (the consumption of carbothioamide 3a was verified by chromatography), diluted with small amount of water and cooled. Yield $0.71 \mathrm{~g}$ (83\%) of final product 5a with m.p. $133-135^{\circ} \mathrm{C}$, (from dimethylformamide).

Elemental analysis and NMR data: Calculated of $\mathrm{C}_{24} \mathrm{H}_{23} \mathrm{~N}_{5} \mathrm{OS}$ 5a, \%: C-67.11, H-5.40, N-16.30. Found, \%: C-67.10, H-5.42, N-16.33. ${ }^{1}$ H-RMN (DMSO-d $)$, ppm: 6.74-8.61 (m, 14H, =CH, Ar-H, Py-H), $3.42\left(\mathrm{~s}, 6 \mathrm{H},-\mathrm{N}\left(\mathrm{CH}_{3}\right)_{2}\right), 10.46$ (s, NH-CS), 12.24 (s, NH-N=CH). ${ }^{13}$ C-NMR (DMSO-d $), p p m: 187.26(\mathrm{C}=\mathrm{S}), 188.02(\mathrm{C}=\mathrm{O}), 153.41(\mathbf{P y}-\mathrm{CH}=\mathrm{N}-$ NH-), $152.47(-\mathrm{NH}-\mathrm{N}=\mathbf{C H}-\mathrm{Py}), 145.36(\mathrm{Ar}-\mathbf{C H}=\mathrm{CH}), 122.18(\mathrm{Ar}-\mathrm{CH}=\mathbf{C H}-), 144.58\left(-\mathrm{C}_{6} \mathrm{H}_{4}-\mathbf{N H}\right), 40.92\left(\mathrm{CH}_{3}\right), 130.46$, $128.87,121.3$.

Similar procedure was used for the synthesis of N-(4-(3-(pyridin-2-yl)acryloyl)phenyl)-2-(pyridin-2-ylmethylene) hydrazinecarbothioamide 6a with an yield of $77 \%$, m.p. $192-194^{\circ} \mathrm{C}$.

Elemental analysis and NMR data: Calculated of $\mathrm{C}_{21} \mathrm{H}_{17} \mathrm{~N}_{5} \mathrm{OS} \mathrm{6a}$ \%: C-65.10, H-4.42, N-18.08. Found, \%: C-65.72, H-4.62, N-18.33. ${ }^{1} \mathbf{H}-\mathbf{R M N}\left(\mathrm{DMSO}_{6}\right.$ ), ppm: 7.43-8.68 (m, 14H, =CH, Ar-H, Py-H), $3.42\left(\mathrm{~s}, 6 \mathrm{H},-\mathrm{N}\left(\mathrm{CH}_{3}\right)_{2}\right), 10.64(\mathrm{~s}$, NH-CS), 12.25 (s, NH-N=CH). ${ }^{13}$ C-NMR (DMSO-d $)$, ppm: $188.94(\mathrm{C}=\mathrm{O}), 176.37$ (C=S), 153.08 (Py-CH=N-NH-), $150.48(-\mathrm{NH}-\mathrm{N}=\mathbf{C H}-\mathrm{Py}), 145.47(\mathrm{Ar}-\mathbf{C H}=\mathrm{CH}), 125.57(\mathrm{Ar}-\mathrm{CH}=\mathbf{C H}-), 143.66\left(-\mathrm{C}_{6} \mathrm{H}_{4}-\mathbf{N H}\right), 134.15,125.57,122.33$.

N-(4-(5-(4-(Dimethylamino)phenyl)-4,5-dihydro-1H-pyrazol-3-yl)phenyl)hydrazinecarbothioamide 7a. a) The mixture of $0.70 \mathrm{~g}(0.002 \mathrm{~mol})$ 3-(4-(3-(4-(Dimethylamino)phenyl)acryloyl)phenyl)-1,1-dimethylthiourea 1, $0.22 \mathrm{~g}$ $(0.0044 \mathrm{~mol})$ hydrazine hydrate and $5 \mathrm{~mL}$ of pyridine was let at room temperature for 24 hours and after heated at $90-$ $95^{\circ} \mathrm{C}$ for 3 hours. The resulting crystals were filtered and recrystallized from methanol. Yield $0.54 \mathrm{~g}(77 \%)$ of thioamide 7a with m.p. $173-174^{\circ} \mathrm{C}$.

b) The mixture of $0.61 \mathrm{~g}(0,002 \mathrm{~mol}) 3$-(4-(Dimethylamino)phenyl-1-(4-isothiocyanatophenyl)prop-2-en-1-one 1a, $0.26 \mathrm{~g}(0.0025 \mathrm{~mol})$ hydrazine hydrate and $5 \mathrm{~mL}$ of pyridine was left to stand at room temperature for 24 hours. The consumption of propenone 1a was, verified by chromatography. After the reacting mixture, was heated at $90-95^{\circ} \mathrm{C}$ for 3 hours. The resulting product was isolated like in the case "a". Yield $0.58 \mathrm{~g}(82 \%)$ of thioamide 7a, m.p. $172-174^{\circ} \mathrm{C}$. Elemental analysis and NMR data: Calculated of $\mathrm{C}_{18} \mathrm{H}_{22} \mathrm{~N}_{6} \mathrm{~S}$ 7a, \%: C-60.99, H-6.26, N-23.71. Found, \%: C-61.07, H-6.21, N-23.74. ${ }^{1} \mathrm{H}-\mathrm{NMR}$ (DMSO-d $)$, ppm: $4.73\left(\mathrm{~m}, 2 \mathrm{H}, \mathrm{NH}_{2}\right), 6.69-7.66(\mathrm{~m}, 8 \mathrm{H},=\mathrm{CH}, \mathrm{Ar}-\mathrm{H}), 3.39$ (m, 2H, CH$)$, 10.39 (s, NH-CS), 9.89 (s, NH-NH ${ }_{2}$ ). ${ }^{13}$ C-NMR (DMSO-d $)$, ppm: 176.55 (C=S), 153.45 (Ar-CH-NH=N), 139.26 $\left(-\mathrm{C}_{6} \mathrm{H}_{4}-\mathrm{NH}\right), 63.86\left(-\mathrm{CH}_{2}-\mathrm{C}\left(-\mathrm{C}_{6} \mathrm{H}_{4}-\right)=\mathrm{N}\right), 40.95\left(\mathrm{CH}_{3}\right), 130.44,129.46,127.69,125.54,112.92,63.82$.

The N-(4-(5-(pyridin-2-yl)-4,5-dihydro-1H-pyrazol-3-yl)phenyl)hydrazinecarbothioamide 8a was obtained similarly from 1,1-dimethyl-3-(4-(3-(pyridin-2-il)-acryloyl)-phenyl)thiourea 2 and hydrazine hydrate with an yield of $77 \%$, with m.p. $199-201{ }^{\circ} \mathrm{C}$ (from ethanol).

Elemental analysis and NMR data: Calculated of $\mathrm{C}_{15} \mathrm{H}_{16} \mathrm{~N}_{6} \mathrm{~S}$ 8a, \%: C-57.67, H-5.16, N-26.90. Found, \%: C-57.62, H-5.20, N-26.91. ${ }^{1} \mathrm{H}-\mathrm{NMR}\left(\mathrm{DMSO}_{6}\right)$, ppm: 4.95 (m, 2H, NH $), 7.27-8.58$ (m, 8H, =CH, Ar-H, Py-H), 3.42 (m, $2 \mathrm{H}$, $\mathrm{CH}_{2}$ ), 9.19 (s, NH-CS), 8.53 (s, NH-NH ${ }_{2}$. ${ }^{13}$ C-NMR (DMSO-d $)$, ppm: 179.70 (C=S), $162.16(\mathbf{P y}-\mathrm{CH}-\mathrm{NH}=\mathrm{N}), 150.05$ $\left(\mathrm{Py}-\mathbf{C H}\left(\mathrm{CH}_{2}\right) \mathrm{NH}-\mathrm{N}=\right), 139.74\left(-\mathrm{C}_{6} \mathrm{H}_{4}-\mathrm{NH}\right), 64.89\left(-\mathrm{CH}_{2}-\mathrm{C}\left(-\mathrm{C}_{6} \mathrm{H}_{4}-\right)=\mathrm{N}\right), 149.44,129.28,125.85,122.49,64.89$.

N-(4-(5-(4-(dimethylamino)phenyl)-4,5-dihydro-1H-pyrazol-3-yl)phenyl)-2-(pyridin-2-ylmethylene)hydrazinecarbothioamide 9a. To a solution of $0.7 \mathrm{~g}(0.002 \mathrm{~mol}) \mathrm{N}-(4-(5-(4-($ dimethylamino $)$ phenyl)-4,5-dihydro-1Hpyrazol-3-yl)phenyl)hydrazinecarbothioamide $7 \mathrm{a}$ and $8 \mathrm{~mL}$ of $\mathrm{CH}_{3} \mathrm{COOH}$ was added under stirring $0.22 \mathrm{~g}(0.002 \mathrm{~mol})$ of 2-formylpyridine. The reacting mixture was let at room temperature for 24 hours and after heated at $70-80^{\circ} \mathrm{C}$ for 2 hours. After, the resulting mixture was neutralized with a solution of $\mathrm{NaHCO}_{3}$. The resulting crystalline product was filtered and recrystallized from acetone. Yield $0.53 \mathrm{~g}(60 \%)$ of final product with m.p. $168-169^{\circ} \mathrm{C}$.

Elemental analysis and NMR data: Calculated of $\mathrm{C}_{22} \mathrm{H}_{26} \mathrm{~N}_{6} \mathrm{~S}(9 \mathrm{9a}), \%$ : C-67.84, H-5.92, N-18.99. Found, \%: C-67.65, H-5.75, N-18.41. ${ }^{1} \mathbf{H}-$ NMR (DMSO-d $)$, ppm: 6.52-8.63 (m, 13H, =CH, Ar-H, Py-H), 3.73 (m, $\left.2 \mathrm{H}, \mathrm{CH}_{2}\right), 10.34(\mathrm{~s}$, NH-CS), $12.18(\mathrm{~s}, \mathbf{N H}-\mathrm{N}=\mathrm{CH}), 3.62\left(\mathrm{~s}, 6 \mathrm{H},-\mathrm{N}\left(\mathrm{CH}_{3}\right)_{2}\right) .{ }^{13} \mathrm{C}-\mathrm{NMR}\left(\mathrm{DMSO}-\mathrm{d}_{6}\right), \mathrm{ppm}: 178.26(\mathrm{C}=\mathrm{S}), 156.26(\mathbf{P y}-\mathrm{CH}=\mathrm{N}-$ NH- $\left.), 152.73(-\mathrm{NH}-\mathrm{N}=\mathbf{C H}-\mathrm{Py}), 52.03\left(\mathrm{Ar}-\mathbf{C H}-\left(\mathrm{CH}_{2}\right) \mathrm{NH}-\mathrm{N}=\right), 140.16\left(-\mathrm{C}_{6} \mathrm{H}_{4}-\mathbf{N H}\right), 64.95\left(-\mathrm{CH}_{2}-\mathrm{C}_{\left(-\mathrm{C}_{6}\right.} \mathrm{H}_{4}^{-}\right)=\mathrm{N}\right), 149.98$, $133.89,129.20,127.30,122.90$.

N-(4-(5-(pyridin-2-yl)-4,5-dihydro-1H-pyrazol-3-yl)phenyl)-2-(pyridin-2-ylmethylene)- hydrazinecarbothioamide 10a. To the solution of $0.62 \mathrm{~g}(0.002 \mathrm{~mol}) \mathrm{N}-(4-(5-($ pyridin-2-yl)-4,5-dihydro-1H-pyrazol-3-yl)phenyl) hidrazinecarbothioamide 8a and $8 \mathrm{~mL}$ of dimethylformamide was added under stirring $0.22 \mathrm{~g}(0.002 \mathrm{~mol})$ of 2-formylpyridine, previously dissolved in $1 \mathrm{~mL}$ of ethanol. The reacting mixture was heated at $70-80^{\circ} \mathrm{C}$ for 2 hours, after diluted with water and cooled to room temperature. The resulting crystalline product was filtered and recrystallized from ethanol. Yield $0.48 \mathrm{~g}(63 \%)$ of final product 10a with m.p. $140-142^{\circ} \mathrm{C}$.

Elemental analysis and NMR data: Calculated of $\mathrm{C}_{21} \mathrm{H}_{19} \mathrm{~N}_{7} \mathrm{~S}$ (10a), \%: C-62.82, H-4.77, N-24.42. Found, \%: C-62.85, 
H-4.75, N-24.41. ${ }^{1}$ H-NMR (DMSO-d $)$ ), ppm: 6.10-8.67 (m, 13H, =CH, Ar-H, Py-H), 3.33 (m, 2H, CH $)$, 10.42 (s, NHCS), 12.22 (s, NH-N=CH). ${ }^{13}$ C-NMR (DMSO-d $)$, ppm: $176.66(\mathrm{C}=\mathrm{S}), 158.18(\mathbf{P y}-\mathrm{CH}=\mathrm{N}-\mathrm{NH}-), 152.16(-\mathrm{NH}-\mathrm{N}=\mathbf{C H}-$ Py), 152.07 (Py-CH- $\left.\left(\mathrm{CH}_{2}\right)-\mathrm{NH}-\mathrm{N}=\right), 139.30\left(-\mathrm{C}_{6} \mathrm{H}_{4}-\mathrm{NH}\right), 64.95\left(-\mathrm{CH}_{2}-\mathrm{C}\left(-\mathrm{C}_{6} \mathrm{H}_{4}^{-}\right)=\mathrm{N}\right), 143.98,138.89,129.28,127.79$.

\section{Cytotoxicity Assay}

Cell culture. Human promyelocytic leukemia cells HL-60 (ATCC, Rockville, MD, USA) were routinely grown in suspension in 90\% RPMI-1640 (Sigma, Saint Louis, USA) containing L- glutamine (2 mM), antibiotics (100 IU penicillin $/ \mathrm{mL}, 100 \mathrm{mg}$ streptomycin $/ \mathrm{mL}$ ) and supplemented with $10 \%(\mathrm{v} / \mathrm{v})$ foetal bovine serum $(\mathrm{FBS})$, in a $5 \% \mathrm{CO}_{2}$ humidified atmosphere at $37^{\circ} \mathrm{C}$. Cells were currently maintained twice a week by diluting the cells in RPMI 1640 medium containing $10 \%$ FBS.

Cell proliferation assay. The cell proliferation assay for compounds and ligands was performed using 3-(4,5-dimethylthiazol-2-yl)-5-(3-carboxymethoxyphenyl) 2-(4-sulfophenyl)-2H-tetrazolium (MTS) (Cell Titer 96 Aqueous, Promega, USA), which allowed us to measure the number of viable cells. In brief, triplicate cultures of 10,000 cells in a total of $100 \mathrm{~mL}$ medium in 96-well microtiter plates (Becton Dickinson and Company, Lincoln Park, NJ, USA) were incubated at $37^{\circ} \mathrm{C}, 5 \% \mathrm{CO}_{2}$. All compounds were dissolved in ethanol to prepare the stock solution of $1 \mathrm{~J} 1022 \mathrm{M}$. These compounds and doxorubicin (Novapharm, Toronto, Canada) which was used as a positive control were diluted at multiple concentrations $(1$ and $10 \mu \mathrm{M})$ with culture media and added to each well and incubated for 3 days. Following each treatment, MTS $(20 \mu \mathrm{L})$ was added to each well and the mixture was incubated for 4 hours. MTS is, converted to water-soluble colored formazan by dehydrogenase enzymes present in metabolically active cells. Subsequently, the plates were read at $490 \mathrm{~nm}$ using a microplate reader (Molecular Devices, Sunnyvale, CA).

\section{References}

1. Dzurilla, M.; Kristian, P. The synthesis infrared and ultraviolet absorption spectra of 4-substituted 3'- and 3'isothiocyanatochalcones. Collection of Czechoslovak Chemical Communications, 1970, 35, pp. 417-429.

2. Barbă, N.; Luchiţa, G.; Barbă, A.; Vieru, R. Process for isothiocyanatochalcones preparation, Patent for invention MD 2985, 2004 (in Romanian).

3. Kessler, M.A.; Meinitzer, A.; Wolfbeis, O.S. Albumin Blue 580 fluorescence assay for Albumin. Analytical Biochemestry, 1997, 248, pp.180-182.

4. Popusoi, A.; Barba, N.; Dragalina, G.; Culeac, I.; Robu, Ş. Synthesis and study of materials of copolymers of luminophores 4-aminostiren grafted with isothiocyantochalcones. The XXXI-st Romanian Chemical Conference, Romania, 2010, p. 141 (in Romanian).

5. Pelkis, P.S.; Pereteajco M.Z. Synthesis of substituted 1,4-diphenylthiosemicarbazides. Russian Journal of General Chemistry, 1961, XXXI(11), pp. 3726-3728 (in Russian).

6. Yousef, T.A.; Badria, F.A.; Ghazy, S.E. In vitro and in vivo antitumor activity of some synthesized 4-(2-pyridyl)3-Thiosemicarbazides derivatives. International Journal of Medicine and Medical Sciences, 2011, 3, pp. 37-46.

7. Gutu, Ia.; Boi, L.V.; Barba, N. Process for 4-aryl and 1,4-diarylthiosemicarbazides preparation. Inventor's certificate USSR 1643533, 15, 1991 (in Russian).

8. Suvitha, S.; Siddig, I. A. Synthesis of Chalcones with Anticancer Activities. Molecules, 2012, 17, pp. 6179-6195.

9. Hu, K.; Yang, Z.H.; Pan, S.S.; Xu, H.J.; Ren, J. Synthesis and antitumor activity of liquiritigenin thiosemicarbazone derivatives. European Journal of Medicinal Chemistry, 2010, 45, pp. 3453-3458.

10. Hong-Jia, Z.; Yong, Q.; Di-Di, Z.; Xu-Guang, Y. Synthesis, molecular modeling and biological evaluation of chalcone thiosemicarbazide derivatives as novel anticancer agents. European Journal of Medicinal Chemistry, 2011, 46, pp. 4702-4708.

11. Ozan, R.; Zuhal, O.; Unsal, C. Synthesis of and Pharmacological Studies on The Antidepressant and Anticonvulsant Activites of Some 1,3,5-trisustituted pyrazolines. Arzneim-Forsch. Drug Research, 2005, 55(8), pp. 431-436.

12. Robinson, T.P.; Hubbard, R.B.; Ehlers, T.J.; Arbiser, J.L.; Goldsmithd, D.J.; Bowena, J.P. Synthesis and biological evaluation of aromatic enones related to curcumin. Bioorganic Medicinal Chemistry, 2005, 13, pp. 4007-4013.

13. Gulea, A.; Poirier, D.; Roy, J.; Stavila, V.; Bulimestru, I.; Țapcov, V.; Bârcă, M.; Popovsch, L. In vitro antileukemia, antibacterial and antifungal activities of some $3 \mathrm{~d}$ metal complexes: Chemical synthesis and structure-activity relationships. Journal of Enzyme Inhibition and Medicinal Chemistry, 2008, 23, pp. 806-818. 